\title{
The Development of the Czech Defence Policy in 2017-2018
}

\begin{abstract}
The Czech Defence policy in 2017 and in the first half of 2018 was influenced mainly by the perceived Russian threat, terrorism and migration - nevertheless, Brexit and the new U.S. administration under President Donald Trump were also important external drivers. These factors resulted in various steps taken within the Czech defence sector, ranging from the adoption of refurbished national strategic documents, an increased defence budget, high (yet still problematic) support from the public and the rising numbers of Armed Forces personnel to problems with age structure both within the military and the civilian institutions of the defence sector. Finally, Czech foreign and security policy are likely to be heavily influenced by the result of the parliamentary elections in October 2017 and by the new government of Andrej Babiš during 2018. The author offers an analysis of the strategic drivers of the Czech defence policy to shed light on the synergies and discrepancies of strategic planning and the realisation of these plans.
\end{abstract}

Keywords: The Czech Republic, NATO, European Union, defence policy, strategy, armed forces

\section{External threats and challenges and defence policy reactions}

In October 2017, parliamentary elections were held in the Czech Republic and during the last months of the year, there was a heated campaign before the presidential elections held in January 2018. Both elections are likely to have important security and foreign policy implications in the future as well. However, besides that, the ongoing trends from previous years still dominated 2017. These can be classified in two subgroups.

The first group consists of threats dominated by an assertive Russia, migration from North Africa and the Middle East, and finally terrorism and cyber-related threats with other implications, such as hybrid, asymmetric and information warfare. The second group influencing Czech foreign and security policy consists of challenges such as Brexit (and its security effects) and the accession of the new U.S. President Donald Trump with his push for $2 \%$ of GDP to be spent on defence.

All these threats and negative trends may be seen as fundamental drivers of the Czech foreign, security and defence policy. While various strategic documents of the Czech Republic clearly underline threats from the first group, for example most recently

This work was commissioned by the National University of Public Service under the priority project PADOP-2.1.2CCHOP-15-2016-00001 entitled "Public Service Development Establishing Good Governance" in the "Strategic Analyses for Supporting Governmental Decision-making in the Field of Foreign and Security Policy" research project run by the Institute for Strategic and Defence Studies. 
the updated version of the Defence Strategy of the Czech Republic ${ }^{2}$ (2017) or previously the Security Strategy of the Czech Republic ${ }^{3}$ (2015), the second group of challenges may be identified in the particular steps undertaken by the Czech political elite and institutions, such as the Ministry of Defence and the Ministry of Foreign Affairs.

\section{Threats as drivers of defence policy}

Regarding the first group of perceived threats, Russia seemed to be the most important driver of the Czech foreign and security policy in 2017. The 2017 Defence Strategy assesses Russia as a very strong threat and states that since 2014 Russian activities on the eastern flank of NATO have been troubling political elites, as well as the population of member and some non-member states. The Czech Republic mostly accents the fact that in Eastern Europe the Russian Federation blatantly pursues its increasing power ambitions, also through the use of military force. In doing so, the Russian Federation violates generally accepted norms of international law, including the territorial integrity of its neighbouring states. ${ }^{4}$ It has executed hybrid operations against NATO nations and EU member states, including targeted disinformation activities and cyberattacks, which are highly visible in times of elections. The latest example of this behaviour was the attempted assassination of the Russian ex-double agent Sergei Skripal in the United Kingdom in March 2018, using a chemical substance under the nickname "Novichok". However, Russia denied responsibility and accused the Czech Republic of producing Novichok, allegedly because the Armed Forces of the Czech Republic are specialised in the defence against weapons of mass destruction. ${ }^{5}$

As for migration, its influence on the Czech Republic was rather limited in absolute numbers of migrants in 2017. For example, during the first six months of 2017 there have been only 2,244 cases of illegal entry and stay on the territory of the Czech Republic, ${ }^{6}$ mostly from Ukraine, Vietnam and Russia. Meanwhile the Czech police stated that they had detained only 172 migrants throughout 2017 who sought to illegally transit the Czech Republic, mostly coming from Austria and heading onwards to neighbouring Germany. These people were coming mainly from Afghanistan, Iraq and Syria. ${ }^{7}$ Furthermore, as of November 2017, there have only been 116 asylum seekers in the Czech Republic altogether. Nevertheless, the topic itself remained very influential, especially before parliamentary and presidential elections. During the parliamentary elections, strong politicisation of this topic helped the anti-immigration and allegedly populist Freedom and Direct Democracy

The Defence Strategy of the Czech Republic, [online], 2017, Ministry of Defence of the Czech Republic. Source: Army.cz [01.02.2018.]

3 Security Strategy of the Czech Republic, [online], 2015, Government of the Czech Republic. Source: Vlada.cz [13.02.2018.]

4 The Defence Strategy of the Czech Republic... (2017).

5 Czechs tested Novichok-like substance for chemical warfare protection: government, [online], 04.05.2018. Source: Reuters [13.02.2018.]

6 Nelegální migrace za období od 1.1.2017 do 30.6.2017 [Illegal migration from 01.01.2017 to 30.06.2017], [online], 03.08.2017. Source: Policie.cz [19.03.2018.]

Migration drops near zero in Czech Republic but sways election campaign, [online], 23.01.2018. Source: Reuters.com [19.02.2018.] 
party (Svoboda a prímá demokracie) led by Tomio Okamura to gain $10.64 \%$ of the votes which translated to 22 seats out of 200 in the Czech Chamber of Deputies. ${ }^{8}$ Aside from that, the topic of migration was, in one form or another, present in programs of several other political parties and may have influenced their outcome in elections. Migration is nevertheless rarely accented alone and is - also in Defence Strategy 2017 - rather closely connected with the threat of terrorism.

The last item of the group of threats - terrorism - is more broadly described in Defence Strategy 2017 as coming from an arc of instability to the south and southeast of Europe. It is rapidly spreading throughout regions from North Africa to Afghanistan, even though in 2017 it was severely weakened with the almost complete annihilation of the so-called "Islamic State" (ISIS). This instability nevertheless stems, in large part, from the fragile states that have allowed non-state actors such as ISIS and other extremist groups to create a zone of instability which extends to the European borders and threatens Europe with the growth of radicalisation, extremism, terrorism, and also an alarming increase of illegal migration into the EU. ${ }^{9}$ In 2017-2018 (or any previous year for that matter) there has been no terrorist attack in the Czech Republic of similar nature to those that happened in France, in the United Kingdom, etc. However, attacks in other countries, particularly their new form of vehicle ramming attacks received substantial domestic media coverage in the Czech Republic. That was especially true for the London Bridge attack in June 2017 or a similar attack in Barcelona in August. In response, discussions and commentaries about the need to secure public spaces in the Czech Republic received considerable attention. ${ }^{10}$

\section{Challenges and their influence on the Czech defence policy}

Out of the second group of trends influencing the Czech foreign and security policy, Brexit represents a significant issue to be dealt with. Already in 2016, one of the immediate responses of the Czech Republic to the UK announcing its intent to leave the European Union was the call from some members of the political elite for the creation of an EU army which was echoed even by Western media. ${ }^{11}$ This call was particularly strong from President Miloš Zeman and (then) Prime Minister Sobotka, who repeatedly stated in 2016 and 2017 that "only EU-wide armed forces will allow us to defend our interests on our own." ${ }^{12}$ According to the original idea voiced by the Czech Prime Minister during the summer of 2016, the European army was supposed to be used mainly for the defence of the EU borders against migrants and as a sign of European military emancipation (with regards to the U.S.). While not generally accepted, the idea of the common EU army

\footnotetext{
See the website of the Svoboda a př́má demokracie party [Freedom and Direct Democracy], [online], 2017. Source: Spd.cz [18.02.2018.]

9 The Defence Strategy of the Czech Republic... (2017).

10 Cíle teroristů v Česku? Máme je u nosu a sami je islamistům nabízíme, varují bezpečnostní experti [Targets for terrorist attack in CZ? Right under our noses, claim security experts], [online], 24.08.2017. Source: Zpravy.aktualne.cz [18.02.2018.]

11 Czechs and Hungarians call for EU army amid security worries, [online], 26.08.2016. Source: BBC.com [18.02.2018.]

12 GHez, Jeremy et al.: Defence and security after Brexit: A snapshot of international perspectives on the implications of the UK's decision to leave the EU. RAND Corporation, Santa Monica, CA, [online], 2017. Source: Rand.org [18.02.2018.]
} 
spurred considerable debate. ${ }^{13}$ The Minister of Defence, however, quickly rejected it ${ }^{14}$ with the main argument being that even the embryonic phase of building an EU army - the EU battlegroups - is hardly considered a successful project, thus, any further integration would be premature, and would only weaken NATO. More recently, common EU security forces replaced the name common EU army in political discourse.

It was generally recognised among the ruling Czech political elite in 2017 that Brexit is creating space for strengthening military cooperation among EU member states. Member states thus need to enhance defence cooperation. Because of structural changes in both the strategic environment (demand) and the economics of defence (supply), when it comes to technology procurement and weapons manufacturing, there is a strong case for European countries to move beyond their traditional approach to defence co-operation and it is a window of opportunity for the Czech Republic as well. ${ }^{15} \mathrm{~A}$ framework for this enhanced cooperation may be provided by the EU Global Strategy (EUGS) published in June 2016, ${ }^{16}$ which creates room for other follow-up initiatives. Military Planning and Conduct Capability (MPCC), the European Defence Fund (EDF), Coordinated Annual Review on Defence (CARD), as well as the prospect of Permanent Structured Cooperation (PESCO) all emerge at a time when EU member states are seeking to build on the momentum of European defence in response to Brexit mostly through the Implementation Plan on Security and Defence. ${ }^{17}$ The common feature of all these initiatives within the EUGS framework causes stress on the gradual synchronisation of national defence planning cycles and capability development practices. ${ }^{18}$

The second challenge that strongly influenced the Czech foreign, security and defence policy in 2017 was the accession of the new U.S. President, Donald Trump. While the Common Security and Defence Policy of the EU may be in some regards strengthened by Brexit, NATO has been much more influenced by Trump's presidency. The security guarantee provided by NATO and the U.S. was still seen as the cornerstone of security policy for the Czech Republic in 2017. Already in 2016, NATO together with a strong U.S. involvement re-established the deterrence of Russia as one of the main priorities of the alliance and approved the deployment of four multinational battalions in Poland and the Baltic states under the Enhanced Forward Presence format. In 2017, the Czech Republic announced that it will participate in this format from 2018.

What is more pressing for Prague, though, is the U.S. desire under Donald Trump to end the perceived free-riding on U.S. security guarantees and to push European NATO

13 HAMÁČEK, Jan: Proč potřebujeme evropskou armádu [Why do we need an EU Army?], [online], 2016. Source: Cssd.cz [29.03.2018.]

14 NovotNÁ, Kristýna: Evropská armáda je utopie a plýtvání penězi, kritizují politici Sobotku [EU Army is a utopia and a waste of money say political critics of Prime Minister Sobotka], [online], 2016. Source: Echo24.cz [29.03.2018.]

15 Gilli, Andrea - Gilli, Mauro: European Defence Cooperation in the Second Machine Age, [online], 2017. Source: Iss. europa.eu [29.03.2018.]

16 Shared Vision, Common Action: A Stringer Europe. A Global Strategy for the European Union's Foreign and Security Policy, [online], June 2016. Source: Eeas.europa.eu [13.02.2018.]

17 Implementation Plan on Security and Defence, [online], 2016. Source: Eeas.europa.eu [13.02.2018.]

18 FIotT, Daniel: The CARD on the EU defence table, [online], April 2017, European Union Institute for Security Studies (EUISS). Source: Europa.eu [13.02.2018.] 
members to dramatically increase their military spending ${ }^{19}$ to at least $2 \%$ of GDP while simultaneously allocating $20 \%$ of the defence spending for procurement of new materiel. However, it is worth mentioning that this is not a fundamental change in the U.S. approach. In response to the rising concerns about Russia, following her actions against Ukraine, the Obama Administration had taken a similar view on the matter, while many EU countries have been increasing their defence expenditures since 2014. Nevertheless, what was new in 2017 was the initial confrontational tone of the Trump Administration. ${ }^{20}$

\section{Institutional adaptation - New documents and approaches}

As for the Ministry of Defence, main publicly available outcomes of its adaptation to external impulses in 2017 and 2018 may be found in the Defence Strategy of the Czech Republic, approved by the government in March 2017. Partially relevant to this issue is the Armaments and Defence Industry Development and Support Strategy of the Czech Republic until 2025, approved by the government on 19 December 2016. In the first half of 2018, policy negotiations also commenced on the renewal of The Long-Term Perspective for Defence, because the original text is from 2015, thus it requires significant changes. So far, at the date of writing this analysis, only preparatory work has been carried out focusing mainly on the identification of trends and best practices from comparable foreign documents. ${ }^{21}$

The Defence Strategy of 2017 specifically addresses that while the likelihood of a direct military attack against the territory of the Czech Republic is still very low, it cannot be ruled out that the security and/or territorial integrity of some NATO allies or fellow EU member states may be threatened in such a way that it would require the engagement of the Czech Armed Forces in collective operations to ensure the defence of allies. ${ }^{22}$ This applies mainly to the threat of Russia. Thus, in practical terms, NATO commitments also influenced the amendment to the Defence Strategy. From now on and depending on the nature of the crisis, the Czech Republic will be able to deploy a land brigade task force without rotation for a six-month period even for international crisis management operations. If such a task force is not deployed, the Defence Strategy 2017 allows for simultaneous deployment of a sustainable battalion and a company-size land task force, or an air force component, with rotation. That represents a significant increase in the level of political-military ambitions.

19 US-EU relations: ambivalent at best, antagonistic at worst, [online], 28.02.2017. Source: Country.eiu.com [13.02.2018.]

20 Joch, Roman: Trumpova nevyzpytatelná zahraniční politika [Trump’s unpredictable foreign policy], [online], 12.05.2017. Source: Natoaktual.cz [13.02.2018.]

21 The following countries and strategic documents were assessed: Belgium (The strategic vision for Defence 2016-2030); Denmark (Agreement for Danish Defence 2018-2023); France (White Paper on Defence and National Security); Canada (Canada's Defence Policy); the Netherlands (Netherlands Defence Doctrine); Germany (2016 White Paper: Strategic Review and Way Ahead on Security Policy and the Future of the Bundeswehr); Austria (Militärstrategisches Konzept 2017); Poland (The Defence Concept of the Republic of Poland); Slovakia (White Paper on Defence of the Slovak Republic, 2016); United Kingdom (National Security Strategy, Strategic Defence and Security Review 2015); U.S. (National Defence Strategy 2018).

22 ProcházKa, Josef - Chalupová, Ivana: The Czech Republic Defence Strategies: A Comparative Analysis and Qualitative Assessment. In: International Scientific Conference "Strategies XXI" - The Complex and Dynamic Nature of the Security Environment 2017. Centre for Defence and Security Strategic Studies, "Carol I" National Defence University, Bucharest, Romania, 2017, pp. 242-252. 
So far, the previous Defence Strategy from 2012 stipulated that a brigade-size task force may be deployed only in case of NATO's collective defence operations. For international crisis management operations, the Czech Republic was able to assign the forces and assets only up to the size of a battalion task force rotated after a six-month period.

Besides that, the Defence strategy 2017 includes several other important measures, such as the establishment of new units and the rise in the number of soldiers by unprecedented five thousand new troops. So far, the original plans endorsed in the Czech Armed Forces Development Concept 2025 expected reaching only 24,162 soldiers. This promising increase may, however, be a source of problems in the future, since the median age of new recruits is already reaching 27 years and with adding another five thousand troops this trend may even be intensified. Even more pressing was the median age of the soldiers in 2017, which reached 36.6 years. If this number is compared with the median age of soldiers in 2007 , then it can be concluded that it has increased by 4.2 years. On average, members of the Armed Forces are getting older by a margin of 0.4 years per annum. ${ }^{23}$ It may be argued that while increasing the absolute number of soldiers is a positive step envisaged by the Defence Strategy, the prospects of reaching this goal are bleak and implications for the age structure of the Armed Forces are increasingly negative. An even worse trend may be seen among civilian personnel, where the median age reaches almost 51 years - with considerable and obvious effects on the MoD functions.

In conclusion, the 2017 Defence Strategy is mostly threat-based, thus generally a reactive strategy. It provides the Czech Republic with a basic strategic vision in combination with a set of strategic level objectives ("back to the roots": restoring balanced forces and relying on Article 3 of the Washington Treaty, providing resilience within the Czech society, increasing the security of supply). There is also a clear ambition to mitigate the under-financing of the defence sector inherited from the past.

\section{Foreign aspects of the Czech Republic's defence policy}

\section{The Czech Republic and NATO}

The position of the Czech Republic since 2017 concerning NATO was heavily influenced by the changing U.S. policy owing to the new administration of President Donald Trump. During his presidential campaign he accused NATO members of spending insufficient funds on defence. He repeated his criticism later, including on NATO's special meeting (also called mini-summit) in Brussels in May 2017. Trump's criticism from the beginning of his tenure, that "certain member countries owed 'massive amounts of money' to American taxpayers" and that NATO members must finally contribute their fair share was, however, partially mitigated by his reassurance to allies of the continued U.S. commitment to the alliance. In the end, the shock caused by the strong message delivered by the U.S. President worked and at the mini-summit in Brussels in May 2017, NATO's heads of state and government took decisions to improve burden sharing in the alliance. That was also

23 BeDnÁř, Zdeněk: Information support of the human resources management of the Czech Ministry of Defence. 2017. Manuscript submitted to Vojenské rozhledy magazine in January 2018. 
true for the Czech Republic, as Prague announced to pledge efforts to reach the 2\% target for military spending along with presenting concrete plans to American allies of how to reach this goal. So far there has only been commitment on behalf of the Czech government from 2014 to increase defence spending progressively to reach $1.4 \%$ of the GDP in $2020{ }^{24}$ Furthermore, after the visit of the Czech Minister of Defence, Stropnický to the U.S. and meeting with U.S. Secretary of Defense Mattis in early May 2017, the Czech Republic announced that reaching $2 \%$ of the GDP is likely in $2024 .{ }^{25}$ This step is widely seen as a co-operative reacting behaviour to the substantial pressure from the U.S. President. However, similar - that time unfulfilled - promises of substantial increases had repeatedly been made in the past.

In June 2017 then Deputy Minister of Defence, Daniel Koštoval offered an alternative explanation for pledging to reach $2 \%$ of the GDP by voicing the fear of the U.S. political elite and stated that it was getting increasingly difficult to persuade the U.S. population to approve increased defence spending in the U.S., while European allies are not doing enough in that area. This version of explanation sees U.S. pressure for reaching $2 \%$ as motivated not by the perceived threat of Russia or any other challenge for that matter, but rather by purely U.S. concerns.

Nevertheless, in 2017 the Czech defence budget reached only $1.04 \%$ of the GDP, amounting to CZK 52.5 billion. Internally, $16 \%$ of the budget was allocated for procurement, $55 \%$ for personnel costs and $29 \%$ for operations and maintenance.

One of the scarcely mentioned problems, associated with the $2 \%$ concept is the inability to utilise such a high level of spending effectively in the recent conditions of the defence sector in the Czech Republic. According to an internal MoD calculation, to spend the $2 \%$ effectively would require reaching altogether 40.000 (military and civilian) personnel within the defence sector. This number exceeds by far even the 5.000 troops increase promised in the 2017 Defence Strategy. In addition, the personnel costs are expected to be under constant pressure due to the increased recruitment, rising salaries and competition over personnel in the private sector.

The second area necessarily affected by the " $2 \%$ rule" is the share of investments within the defence budget. According to NATO guidance, the funds spent on procurement are supposed to reach $20 \%$ of the entire defence budget. However, during a Ministry of Defence officials' meeting (headed by Deputy Minister of Defence Daniel Koštoval) with members of the U.S. administration in Washington in April 2017, a chart was presented promising the ambition to invest $30 \%$ of the Czech MoD's annual defence budget for the procurement of new equipment starting in 2020, while maintaining this level for another five years. If the life-cycle costs of newly procured equipment are taken into consideration, with $30 \%$ investments the operating costs will also increase dramatically, thus putting heavy strain on the future defence budget.

24 Czech Coalition Agreement, [online], 03.09.2014. Source: Army.cz [13.02.2018.]

25 Ministr Stropnický: Vrtulníky české armádě dodají USA nebo Itálie [Minister Stropnický: Helicopters will be purchased either from the USA or Italy], [online], 02.05.2017. Source: Lidovky.cz [13.02.2018.] 


\section{The EU dimension of the Czech defence policy}

Out of numerous EU-related initiatives within the EUGS framework, perhaps the most publicly discussed one in the Czech Republic during 2017 was PESCO, which is provided for in Articles 42 and 46 of the Treaty on European Union and Protocol No. 10 to the Treaty, formally established in December 2017. ${ }^{26}$ The Czech Republic itself joined PESCO in December 2017 and plans to participate in three out of the total seventeen collaborative projects (Military Mobility Project, building of the European Medical Command and finally participation in creating the European Union Training Mission Competence Centre).

For the Czech Republic PESCO is seen as an ambitious, binding and inclusive European legal framework for investments in the security and defence of the EU's territory and its citizens. PESCO provides a crucial political framework to improve military assets and defence capabilities, which will also benefit NATO. It will strengthen the European pillar within the alliance and respond to repeated demands for stronger transatlantic burden sharing. Thus, in the eyes of the Czech political elite, PESCO could be an important element of possible development towards the so much sought common defence. A long-term vision of PESCO is to arrive at a coherent full spectrum force package - in complementarity with NATO, which will continue to be the cornerstone of collective defence for its members. However, the most important outcome of PESCO, voiced loudly by the former Minister of Finance and since December 2017 also the new Prime Minister, Andrej Babiš, is its possibility to create a common defence market ${ }^{27}$ seen as an opportunity for the Czech defence industry. But even this importance was probably realised too late - as the Armed Forces (and to a lesser degree also the $\mathrm{MoD}$ ) were unofficially blamed by the Ministry of Foreign Affairs for putting too little emphasis on preparation works of PESCO, as well as for showing a lack of initiative in pushing through projects that may be relevant for the Czech Republic.

\section{Defence cooperation and foreign operations in 2017-2018}

The highest number of Czech soldiers abroad in 2017 operated again in NATO's Resolute Support Mission in Afghanistan. In 2017, the Czech Army had a mandate to send 270 soldiers there with another twenty soldiers solely for the protection of the Czech Embassy in Kabul. Apart from patrolling, the Czech contingent in the Resolute Support was also tasked with the protection of the allied forces and training of their Afghan counterparts. ${ }^{28}$ As of May 2018, there were 245 soldiers in Afghanistan with further possible 140 reinforcements coming in the second half of 2018.

26 Speech by President Jean-Claude Juncker at the Defence and Security Conference Prague: In defence of Europe, [online], 09.06.2017. Source: Europa.eu [13.02.2018.]

27 Babiš v Bruselu stvrdí zapojení do armády EU, projekt PESCO vede k jednotnému trhu obrany [Babiš in Brussels confirms involvement in the EU army - PESCO is the road to the common defence market], [online], 14.12.2017. Source: Ceska-justice.cz [13.02.2018.]

28 Gov’t approves military's foreign priorities for 2017-2018, [online], 19.04.2016. Source: Praguemonitor.com [13.02.2018.] 
The CZAF also continued their missions in Mali in 2017 by sending the second most numerous contingent in history: altogether sixty soldiers served there. The bulk of this force was part of the EU training mission EUTM Mali, while ten soldiers served in the staff positions of the United Nations-led mission MINUSMA. Finally, as of the second half of 2018, the number of soldiers should rise to 120 in EUTM Mali and to 30 in MINUSMA.

Most of the other operations abroad were considerably smaller with only one exception - MFO on Sinai - consisting of twenty-five troops with a CASA transport aircraft. Apart from these, the Czech Republic deployed smaller contingents in numerous operations led by the EU, but also the UN and OSCE, such as EU NAVFOR MED Sophia with five soldiers or the UN mission UNDOF on Golan Heights with three soldiers, etc.

The Czech Republic did not participate in the NATO Enhanced Forward Presence format in the Baltic states in 2017 but announced its involvement for the year 2018 with the prospect of the deployment of up to 290 troops in Lithuania and Latvia. A mechanised company with the bulk of the forces (up to 250 troops) will serve under German command in Lithuania and a forty-men-strong mortar platoon under Canadian command will be deployed in Latvia. ${ }^{29}$

As a part of the package deal of selling L-159 light combat aircrafts to Iraq, the Czech Republic already sent an advisory team to the Operation Inherent Resolve in Iraq to help train the local air force in 2016. This represents probably the greatest Czech contribution to fighting the so-called "Islamic State". In 2017, this deployment continued with up to thirty-five soldiers (pilots, instructors and ground technicians). Additional capabilities included the Field Surgical Team which returned home on 17 June 2017 and a five to ten troops strong military police training team sent to Iraq on 4 November 2017. A decision to deploy the CBRN Military Training Team in 2018 was also taken. ${ }^{30}$ Since this package of missions is fundamentally bilateral in nature, it represents one of the rare examples of purely proactive offensive actions of the Czech foreign and security policy in 2017.

In April 2018, the number of soldiers in foreign missions was increased by further 270 , while the currently existing plans specified that for 2018 only 806 soldiers should be deployed. ${ }^{31}$ This increase should cost around 2.5 billion CZK annually.

A notable project regarding interoperability with allies which was envisaged in 2017 is the planned affiliation of the Czech $4^{\text {th }}$ Rapid Deployment Brigade with the German $10^{\text {th }}$ Armoured Division and Rapid Response Forces Division. This integration (which also includes Romania's $81^{\text {st }}$ Mechanised Brigade) has been agreed upon on 15 February 2017 under NATO's Framework Nation Concept. The affiliation of the $4^{\text {th }}$ Rapid Deployment Brigade is to be organised at the tactical level of the German Division, which will allow the already planned exercises and trainings to be used as entry points for further practical co-operation. The affiliation will be mainly focused on common activities of staff elements and affiliated units, education and harmonisation of military requirements,

\footnotetext{
Bulletin of the Czech Foreign Policy Data VII-IX, [online], 2017, p. 31. Source: Mzv.cz [13.02.2018.]

Current Deployments - Iraq, [online], 2017. Source: Army.cz [08.04.2018.]

31 Vláda schválila rozšíření zahraničních misí české armády [The government approved the expansion of the Czech Army's foreign missions], [online], 11.04.2018. Source: Cesky.radio.cz [08.04.2018.]
} 
common training procurement and logistical support. ${ }^{32}$ In practical terms, this affiliation was, however, strongly critically politicised by Czech opposition parties in the first half of 2017 and this critique also appeared in influential magazines such as Foreign Policy. ${ }^{33}$ It was mostly based on the misunderstanding of the implications of affiliation. This step has been wrongly seen as putting the CZAF under the German command and integrating both armies. In reality, it will be focused on systematic common training with German soldiers at divisional level, at which the CZAF themselves cannot train on their own (due to the fact that the highest-level units are only brigades). Additionally, it will bring benefits of utmost importance for command and staff development, rather than for soldiers in basic assignments.

\section{Political and military leadership}

The year 2017 was outstanding in terms of dramatic changes of key actors influencing the foreign and security policy of the Czech Republic. This was due to the parliamentary elections in October 2017 which brought the old coalition - composed of ČSSD (the Czech Social Democratic Party), ANO (Action of Dissatisfied Citizens) and KDU-ČSL (Christian and Democratic Union - Czechoslovak People's Party) - to an end. The Prime Minister of this old coalition was Bohuslav Sobotka (ČSSD), known as a supporter of greater EU integration with a possible creation of the EU army in the future. One of his strongly voiced arguments regarding security issues and namely migration was his opposition against EU quotas on migrants. ${ }^{34}$

Following the parliamentary elections in October 2017, Sobotka's government resigned and the former Minister of Finance, Andrej Babiš was appointed Prime Minister on 6 December 2017. He had mostly been known for omitting security topics from his agenda. However, protection against the threat of migration was one of his key pre-election themes. ${ }^{35}$ Nevertheless, he seems to put a strong emphasis on foreign, security and defence policy from a purely economic point of view and does not have a clear stance and strong position on foreign policy.

Until 2017, another member of ČSSD, Lubomír Zaorálek held the post of the Minister of Foreign Affairs, whose stance on migration mimicked that of the Prime Minister. In March 2017, during an interview for the newspaper Hospodářské Noviny, speaking about migration, Zaorálek said: "When you have two million people coming from the east who take your jobs, social support and a number of other things, you can (try to) persuade your own people a thousand times to get used to it. They will not take it, because you simply went too far, and you did not tell them the truth." ${ }^{36}$ After Zaorálek became the Social Democratic

32 Letter of Intent between the Ministry of Defence of the Czech Republic and the Federal Ministry of Defence of the Federal Republic of Germany, [online], 2017. Source: Army.cz [23.02.2018.]

33 BRAw, Elisabeth: Germany Is Quietly Building a European Army under Its Command, [online], 22.05.2017. Source: Foreignpolicy.com [24.02.2018.]

34 GHez et al. (2017): op. cit.

35 Andrej Babiš v regionu nastínil své hlavní volební téma: Bezpečnost. Vlastní imigrační politika. Ne diktát z Bruselu. A ten Putin... [Andrej Babiš hinted his main pre-election topic: Security, our own immigration controls. No to dictate from Brussels. And Putin...], [online], 28.07.2017. Source: Parlamentnilisty.cz [24.02.2018.]

36 Czech foreign minister: free movement could break up the EU, [online], 20.03.2017. Source: Reuters.com [24.02.2018.] 
candidate for Prime Minister in the second half of 2017 during the pre-election campaign, he warned that the West had about twenty years to reach a settlement with the Muslim world. ${ }^{37}$ This position is partially related to one of the last announcements Zaorálek did as Minister of Foreign Affairs in 2017. At the beginning of December 2017, U.S. President Donald Trump stated that the United States was preparing a plan of transferring its embassy from Tel Aviv to Jerusalem. In an immediate reaction to Trump, Zaorálek's office said the Czech Republic might be considering the transfer of its own embassy only after discussing the issue with its partners. Thus, Zaorálek's position was that the Czech Republic considers Jerusalem the future capital of Israel and the State of Palestine, as do the other EU members, but denied planning to move its embassy there. ${ }^{38}$

On the other hand, transferring the Czech embassy to Jerusalem was a long-term goal of President Miloš Zeman. For him the year 2017 was a year of campaigning for re-election - a task he successfully accomplished in January 2018. His foreign policy stance has long been accused of being too pro-Russian, ${ }^{39}$ even though he himself was a strong supporter of U.S. President Trump. A well-known evergreen topic of the Czech foreign policy in 2017 with obvious security implications was the expected invitation of Miloš Zeman to the White House, which in the end did not take place. This has been a source of ridicule for Zeman's domestic political opponents and explained as a sign that the president may be a persona non grata in the U.S. However, Zeman held talks with Russian President Putin in Sochi in November 2017. During his visit there, articles praising the Soviet occupation of Czechoslovakia in 1968 appeared on the website of the Russian Army TV network Zvezda only to be immediately denounced and criticised by a large part of the domestic political elite, including Zeman himself..$^{40}$ Despite this criticism, Zeman managed to win the presidential election in January 2018, thus securing himself the second term in office.

Since 2014, Martin Stropnický held the post of the Minister of Defence. He remained in that post since the very end of Sobotka's government making him the longest serving minister of defence in the history of the Czech Republic. In the first government of Andrej Babiš in December 2017, Stropnický was designated to become the minister for foreign affairs, as well as the deputy prime minister, assuming both posts on 13 December 2017. In May 2018, his post was offered to ČSSD as part of the coalition deal; Stropnický will likely receive an ambassadorial post in Israel. The post of minister of foreign affairs in the second Babiš (coalition) government was supposed to be assigned to ČSSD and one of its leading members, Miroslav Poche. However, since he has also been known as an opponent of the current President Zeman, eventually he was not appointed Minister of Foreign Affairs, but temporarily this post was assigned to the new Minister of the Interior and head of ČSSD, Jan Hamáček.

37 Growing awareness of colonial past fuels radicalisation, says Czech minister, [online], 15.06.2017. Source: Theguardian. com [24.02.2018.]

38 Foreign Minister: Czechs not abandoning EU stance on Jerusalem, [online], 12.12.2017. Source: Praguemonitor.com [24.02.2018.]

39 JandA, Jakub: How Czech President Miloš Zeman Became Putin’s Man, [online], 26.01.2018. Source: Observer.com [24.02.2018.]

40 ForMin: Czech delegation should speak of 1968 invasion in Russia, [online], 22.11.2017. Source: Praguemonitor.com [24.02.2018.] 
The previous Minister of Foreign Affairs, Stropnický has been known as a harsh critic of Russian interference in domestic politics and of Russian politics on the eastern flank of NATO. He is also a strong supporter of the Transatlantic bond which he sees as a cornerstone of allied security guarantees to the Czech Republic. During his mandate as MoD, he had overseen the sharp increase of the defence budget from CZK 42 billion in 2014 to 52.5 billion in 2017 . However, his critics point to the fact that despite such rapidly growing budget he was unable to finish the promised procurement cycle of any major military hardware such as new multipurpose helicopters, Mobile Air Defence Radars (MADR) or procuring new NATO-calibre hand guns ${ }^{41}$ As a minister of foreign affairs, he supported British, American and French air strikes in Syria in April 2018 in response to the alleged use of chemical weapons by the Syrian Arab Army.

His position in the MoD was taken in the first Babiš Government in late 2017 and kept till June 2018 when Karla Šlechtová replaced him, who - despite being nominated by the ruling ANO party - was seen as a figurehead of President Miloš Zeman and was also allegedly disliked by Prime Minister Babiš. She has been known as a harsh critic of the ineffectiveness of the Armed Forces leadership, and also a critic of her predecessor's inability to finish the procurement programs. In May 2018 news surfaced about a possible coalition deal which would leave the post of MoD for the ČSSD (the Czech Social Democratic Party). However, when this coalition government was formed, the then Minister of the Interior Lubomír Metnar was assigned to lead the MoD in late June 2018.

The personal situation remained mostly stable on the side of the military. On 1 August 2017, Major General Aleš Opata returned to the Czech Republic from the position of the national military representative of the Czech Republic to the NATO SHAPE (Mons) and became the Deputy Chief of the General Staff - Chief of Staff. At that time, he had already been considered as a future chief of the General Staff, thus replacing general Josef Bečvár. This was confirmed in April 2018. That, however, meant the end of the professional career of Lieutenant General Miroslav Žižka, who held the post of the NATO and EU military representative of the Czech Republic until the end of July 2017 and after his return did not receive any assignment within the Armed Forces. This step was briefly criticised in the media with active co-operation from General Žižka himself. ${ }^{42}$

\section{Society and the Armed Forces}

Media and public discourse regarding foreign, security and defence policy in 2017 and 2018 has mostly just mimicked topics related to the threats and tendencies of the security environment described in the first chapter. However, besides that, a few other recurring themes became visible in the public discourse as well.

41 Stratilík, Ondřej: Hamáček: Stropnický selhal, není schopný dotáhnout velké nákupy [Hamáček: Stropnický failed, he is unable to finish major acquisitions], [online], 10.02.2017. Source: Euro.cz [30.03.2018.]

42 GAZDík, Jan: "Nemáme pro vás místo." Odcházím bez zášti, tvrdí elitní generál Žižka, vyhozený z generálního štábu ["We do not have place for you." I am leaving without hatred, says general Žizka who was fired from the General Staff], [online], 04.11.2017. Source: Zpravy.aktualne.cz [30.03.2018.] 
In the case of the Czech Republic "strategic communication" as a rather newly coined term was reactive rather than proactive in 2017-2018. The result is an alarmingly low knowledge of ordinary citizens about the defence sector. Only $20 \%$ of the respondents in the public surveys were able to estimate the size of the CZAF or the defence budget correctly. The natural outcome is that just $43 \%$ of the respondents are willing to participate in the defence of the country in case of war. ${ }^{43}$ The Ministry of Defence has currently continued its work on the Strategic Communications Concept in 2017. One of the key preconditions was that it should be aligned with other ministries as well, with the Ministry of the Interior in the lead.

Among others, defence-related issues which were politicised and featured in the media in 2017 was the ongoing discussion about the possibility to re-introduce conscription, supported by the fact that $42 \%$ of Czech citizens believe that abolishing conscription in the past was wrong. This topic was even partially reflected in the programmes of some of the political parties for the October 2017 parliamentary elections (KDU-ČSD, Mayors and Independents and a few other non-parliamentary parties). However, the weak election results of these parties may also reflect disinterest of the population to participate in defence. Thus, even though $86 \%$ of the respondents in public surveys claimed that they are interested in defence and $81 \%$ had high trust in the Armed Forces, merely $9 \%$ of citizens indicated willingness to participate in defence of the state as a part of the Armed Forces in case of need. ${ }^{44}$

However, since the armed forces were expanding rapidly in 2017, the need to bolster recruitment pushed the MoD to intensify its media campaign. One of the sings of this was a TV series produced in co-operation of the MoD and the Czech Television public broadcaster, vividly documenting lives of fresh conscripts in the Active Reserves (a reserve unit of the Armed Forces) called Provedu! Přijimač. The series aired in April-May 2017 with a favourable reception. ${ }^{45}$ However, in 2018 the Armed Forces began to quickly disappear from public discourse owing probably to the decreasing threat perception as well as the unstable situation concerning the government led by Andrej Babiš, that had to face a no-confidence vote in January 2018. In the ensuing coalition negotiations between ANO and ČSSD, the position of the Minister of Defence was repeatedly offered to the ČSSD by Prime Minister Babiš - and later refused by this party in exchange for receiving the Ministry of Foreign Affairs.

\section{Conclusions and remaining challenges}

The Czech foreign, security and defence policy in 2017-2018 was mostly reactive to external threats and challenges. It was reactive in terms of resistance against the Russian threat to NATO allies, as well as in intensifying efforts with regards to the Czech Republic's

\footnotetext{
43 Procházka, Josef - DyčKa, Lukáš: Czech Defence Policy - Critical Assessment and Recommendations. Vojenské rozhledy, Vol. 26, No. 5, 2017, pp. 41-60.

44 DyčKA, Lukáš: Czech Defence Policy Adaptation to Dynamics of the Security Environment. PhD Dissertation, Masaryk University, [online], 2017. Source: Is.muni.cz [30.03.2018.]

45 „Provedu! Přijímač” - hodnocení [Bootcamp: Yes, Sir! - Evaluation], [online], 2017. Source: Cfsd.cz [30.03.2018.]
} 
willingness to accept the push from the U.S. for increasing defence expenditures, where Prague made a clearly voiced promise to reach $2 \%$ of the GDP, despite the fact that currently this aim is more utopian than real. One of the rare cases of proactive actions was sending numerous specialists, pilots, military policemen etc. to Iraq to train the Iraqi Air Forces, using Czech manufactured L-159 light attack planes. This mission is not only based on a bilateral framework unlike the other operations abroad that are usually within the framework of NATO, EU, OSCE or UN, but can also serve as an example of successful military diplomacy and support of the Czech defence industry.

However, there are possible challenges that may hinder the successful development of the Armed Forces in the future. The first is the financing of defence. The inability to spend vastly increasing sums may cause the public to question the need to spend money on defence and thus hinder the realisation of the current ambitious foreign and security policy goals. A low level of investments severely hinders the modernisation of the Armed Forces that still rely heavily on obsolete Soviet platforms (BMP-2, Mi-24 helicopters etc.), making the Czech Republic not only ill-equipped for today's operational environment, but also dependent on Russia. ${ }^{46}$ Finally, the rapidly ageing military, as well as the civilian personnel of the Armed Forces and the MoD will likely hinder the efficient functioning of the defence sector in the future.

\section{REFERENCES}

Andrej Babiš v regionu nastínil své hlavní volební téma: Bezpečnost. Vlastní imigrační politika. Ne diktát z Bruselu. A ten Putin... [Andrej Babiš hinted his main pre-election topic: Security, our own immigration controls. No to dictate from Brussels. And Putin...], [online], 28.07.2017. Source: Parlamentnilisty.cz [24.02.2018.]

Babiš v Bruselu stvrdí zapojení do armády EU, projekt PESCO vede k jednotnému trhu obrany [Babiš in Brussels confirms involvement in the EU army - PESCO is the road to the common defence market], [online], 14.12.2017. Source: Ceska-justice.cz [13.02.2018.]

BEDNÁŘ, Zdeněk: Information support of the human resources management of the Czech Ministry of Defence. 2017. Manuscript submitted to Vojenské rozhledy magazine in January 2018.

BRAW, Elisabeth: Germany Is Quietly Building a European Army Under Its Command, [online], 22.05.2017. Source: Foreignpolicy.com [24.02.2018.]

Bulletin of the Czech Foreign Policy Data VII-IX, [online], 2017. Source: Mzv.cz [13.02.2018.]

Cíle teroristů v Česku? Máme je u nosu a sami je islamistům nabízíme, varují bezpečnostní experti [Targets for terrorist attack in CZ? Right under our noses, claim security experts], [online], 24.08.2017. Source: Zpravy. aktualne.cz [18.02.2018.]

Czech Coalition Agreement, [online], 03.09.2014. Source: Army.cz [13.02.2018.]

Czechs and Hungarians call for EU army amid security worries, [online], 26.08.2016. Source: BBC.com [18.02.2018.]

Czech foreign minister: free movement could break up the EU, [online], 20.03.2017. Source: Reuters.com [24.02.2018.]

Czechs tested Novichok-like substance for chemical warfare protection: government, [online], 04.05.2018. Source: Reuters [13.02.2018.]

Current Deployments - Iraq, [online], 2017. Source: Army.cz [08.04.2018.]

DYČKA, Lukáš: Czech Defence Policy Adaptation to Dynamics of the Security Environment. PhD Dissertation, Masaryk University, [online], 2017. Source: Is.muni.cz [30.03.2018.]

46 ProcházKa-DyčKa (2017): op. cit. 
FIott, Daniel: The CARD on the EU defence table, [online], April 2017, European Union Institute for Security Studies (EUISS). Source: Europa.eu [13.02.2018.]

Foreign Minister: Czechs not abandoning EU stance on Jerusalem, [online], 12.12.2017. Source: Praguemonitor. com [24.02.2018.]

ForMin: Czech delegation should speak of 1968 invasion in Russia, [online], 22.11.2017. Source: Praguemonitor. com [24.02.2018.]

GAZDík, Jan: “Nemáme pro vás místo." Odcházím bez zášti, tvrdí elitní generál Žižka, vyhozený z generálního štábu ["We do not have place for you." I am leaving without hatred, says general Žizka who was fired from the General Staff], [online], 04.11.2017. Source: Zpravy.aktualne.cz [30.03.2018.]

Ghez, Jeremy - Kirchner, Magdalena - Shurkin, Michael - Knack, Anna - Hall, Alexandra - Black, James: Defence and security after Brexit: A snapshot of international perspectives on the implications of the UK's decision to leave the EU. RAND Corporation, Santa Monica, CA, [online], 2017. Source: Rand. org [18.02.2018.] DOI: https://doi.org/10.7249/PE225

GiLli, Andrea - Gilli, Mauro: European Defence Cooperation in the Second Machine Age, [online], 2017. Source: Iss.europa.eu [29.03.2018.]

Gov't approves military's foreign priorities for 2017-2018, [online], 19.04.2016. Source: Praguemonitor.com [13.02.2018.] DOI: https://doi.org/10.1055/s-0038-1627079

Growing awareness of colonial past fuels radicalisation, says Czech minister, [online], 15.06.2017. Source: Theguardian.com [24.02.2018.]

HAMÁČEK, Jan: Proč potřebujeme evropskou armádu [Why do we need an EU Army?], [online], 2016. Source: Cssd.cz [29.03.2018.]

Implementation Plan on Security and Defence, [online], 2016. Source: Eeas.europa.eu [13.02.2018.]

JANDA, Jakub: How Czech President Miloš Zeman Became Putin's Man, [online], 26.01.2018. Source: Observer. com [24.02.2018.]

Joch, Roman: Trumpova nevyzpytatelná zahraniční politika [Trump’s unpredictable foreign policy], [online], 12.05.2017. Source: Natoaktual.cz [13.02.2018.]

Letter of Intent between the Ministry of Defence of the Czech Republic and the Federal Ministry of Defence of the Federal Republic of Germany, [online], 2017. Source: Army.cz [23.02.2018.]

Migration drops near zero in Czech Republic but sways election campaign, [online], 23.01.2018. Source: Reuters. com [19.02.2018.]

Ministr Stropnický: Vrtulníky české armádě dodají USA nebo Itálie [Minister Stropnický: Helicopters will be purchased either from the USA or Italy], [online], 02.05.2017. Source: Lidovky.cz [13.02.2018.]

Nelegální migrace za období od 1.1.2017 do 30.6.2017 [Illegal migration from 01.01.2017 to 30.06.2017], [online], 03.08.2017. Source: Policie.cz [19.03.2018.]

Novotná, Kristýna: Evropská armáda je utopie a plýtvání penězi, kritizují politici Sobotku [EU Army is a utopia and a waste of money say political critics of Prime Minister Sobotka], [online], 2016. Source: Echo24.cz [29.03.2018.]

ProcházKa, Josef - Chalupová, Ivana: The Czech Republic Defence Strategies: A Comparative Analysis and Qualitative Assessment. In: International Scientific Conference "Strategies XXI" - The Complex and Dynamic Nature of the Security Environment 2017. Centre for Defence and Security Strategic Studies, "Carol I" National Defence University, Bucharest, Romania, 2017. pp. 242-252.

ProcházKa, Josef - DyčKa, Lukáš: Czech Defence Policy - Critical Assessment and Recommendations. Vojenské rozhledy, Vol. 26, No. 5, 2017, pp. 41-60. DOI: https://doi.org/10.3849/2336-2995.26.2017.05.041-060

„Provedu! Přijímač” - hodnocení [Bootcamp: Yes, Sir! - Evaluation], [online], 2017. Source: Cfsd.cz [30.03.2018.]

Security Strategy of the Czech Republic, [online], 2015, Government of the Czech Republic. Source: Vlada.cz [13.02.2018.]

Shared Vision, Common Action: A Stronger Europe. A Global Strategy for the European Union's Foreign and Security Policy, [online], June 2016. Source: Eeas.europa.eu [13.02.2018.]

Speech by President Jean-Claude Juncker at the Defence and Security Conference Prague: In defence of Europe, [online], 09.06.2017. Source: Europa.eu [13.02.2018.] 
STRATILík, Ondřej: Hamáček: Stropnický selhal, není schopný dotáhnout velké nákupy [Hamáček: Stropnický failed, he is unable to finish major acquisitions], [online], 10.02.2017. Source: Euro.cz [30.03.2018.]

Svoboda a prímá demokracie party [Freedom and Direct Democracy], [online], 2017. Source: Spd.cz [18.02.2018.] The Defence Strategy of the Czech Republic, [online], 2017, Ministry of Defence of the Czech Republic. Source: Army.cz [01.02.2018.]

US-EU relations: ambivalent at best, antagonistic at worst, [online], 28.02.2017. Source: Country.eiu.com [13.02.2018.]

Vláda schválila rozšíření zahraničních misí české armády [The government approved the expansion of the Czech Army's foreign missions], [online], 11.04.2018. Source: Cesky.radio.cz [08.04.2018.] 